\title{
Cachexia and graft-vs.-host-disease-type skin changes in keratin promoter-driven TNF $\alpha$ transgenic mice
}

\author{
Jian Cheng, ${ }^{1,2}$ Kursad Turksen, ${ }^{1,2}$ Qian-Chun Yu, ${ }^{1}$ Hans Schreiber, ${ }^{3}$ Michael Teng, ${ }^{3}$ \\ and Elaine Fuchs ${ }^{1,4}$ \\ ${ }^{1}$ Howard Hughes Medical Institute, Department of Molecular Genetics and Cell Biology and ${ }^{3}$ Department of Pathology, The \\ University of Chicago, Chicago, Illinois 60637 USA
}

\begin{abstract}
Tumor necrosis factor $\alpha$ (TNF $\alpha)$ orchestrates a wide range of effects that combat severe infections in animals. At lower levels, TNF $\alpha$ plays an important protective role in stimulating chemotaxis and antimicrobial activity of neutrophils, macrophages, and eosinophils. During chronic illness, TNF $\alpha$ secretion can be elevated markedly, giving rise to cachexia, hemorrhage, necrosis and, ultimately, death. Although TNF $\alpha$ may mediate many of its effects through macrophages, $30 \%$ of TNF $\alpha$ injected into animals concentrates in the skin. In recent years, it has been shown that keratinocytes can be induced to synthesize TNFa. To explore the role of TNF $\alpha$ synthesis in keratinocytes, we used a keratin-14 (K14) promoter to target human TNF $\alpha$ expression in the epidermis and other stratified squamous epithelia of transgenic mice. Most mice expressing the K14-TNF $\alpha$ transgene stopped gaining weight within 1 week postbirth, and exhibited retarded hair growth. In the skin, adipose production was profoundly inhibited, whereas signs of fibrosis and immune infiltration were evident in the dermis. Over time, the epidermis exhibited an increased stratum corneum, as signs of necrosis began to appear in the skin. Within 3-5 weeks, the mice displayed features characteristic of cachexia and necrosis. Our results suggest that TNF $\alpha$ expression by keratinocytes not only plays a role in inflammatory and graft-versus-host-disease-like responses in the skin, but also in other tissues, apparently by virtue of stratified squamous epithelial-derived TNF $\alpha$ entering the bloodstream. Our results have enabled the first evaluation of many of the effects of TNFa in transgenic animals.
\end{abstract}

[Key Words: TNF $\alpha$; keratin-14 promoter; epidermal expression; adipose suppression; transgenic mice]

Received March 20, 1992; revised version accepted June 1, 1992.

Tumor necrosis factor $\alpha(\mathrm{TNF} \alpha)$ is a polypeptide (17.3 $\mathrm{kD}$ ) that mediates a wide range of inflammatory and immune responses involving cells of epithelial and myeloid origin (for review, see Beutler and Cerami 1989; Schreiber et al. 1990; Cerami 1992). TNF $\alpha$ was originally discovered as a cytotoxic factor for tumor cells and as a factor involved in cachexia induced by chronic illnesses such as cancer and acquired immunodeficiency sydrome (AIDS) (Carswell et al. 1975; Oliff et al. 1987; Tracey et al. 1988). Elevation of serum/sinovial fluid levels of TNF $\alpha$ has also been associated with endotoxic shock, rheumatoid arthritis, and autoimmunity in graft-vs.-host disease (GVHD) (Beutler et al. 1985, 1986; Sale et al. 1985; Tracey et al. 1986; Piguet et al. 1987; Saxne et al. 1988; Yocum et al. 1989).

Most, if not all, cells possess TNF $\alpha$ receptors. TNF $\alpha$, however, seems to be synthesized by a much smaller repertoire of nontransformed cell types, including activated macrophages, $\mathrm{T}$ cells, natural killer cells, mast

\footnotetext{
${ }^{2}$ These authors contributed equally to this work.

${ }^{4}$ Corresponding author.
}

cells, and keratinocytes (Urban et al. 1986; Djeu et al. 1988; Gordon and Galli 1990; Kock et al. 1990). Much attention has been given to the roles that stimulated induction of TNFs by inflammatory cells might play in TNF-induced responses. Therefore, it is surprising that nearly $30 \%$ of the TNF $\alpha$ intravenously injected into mice concentrates in the skin (Beutler et al. 1985). That skin is susceptible to TNF $\alpha$ has been suspected from the typical cutaneous lesions that occur during the acute phase of GVHD, where serum TNF $\alpha$ levels are elevated (Sale et al. 1985). Indeed, intravenous administration of anti-TNF $\alpha$ antibodies blocked GVHD-induced skin necrosis (Piguet et al. 1987, 1990), further implicating TNF $\alpha$ in immune-related responses of the skin. More recently, culture studies have shown that keratinocyte growth is profoundly, but reversibly, inhibited by nanomolar amounts of recombinant TNF $\alpha$ (Pillai et al. 1989; Symington 1989|. The in vivo effects of constitutive and abnormal TNF $\alpha$ production by keratinocytes have not yet been evaluated, however, nor is it known whether keratinocyte-derived TNF $\alpha$ can act directly or indirectly to influence other TNF $\alpha$-related biological activities. 
The roles of different cell types in manifesting the pleiotropic effects of TNF $\alpha$ remain a major issue in TNF $\alpha$ biology. One approach to investigating this question is to target TNF $\alpha$ overexpression in transgenic mice. Recently, a gene encoding a human TNF $\alpha$ mRNA with a modified 3 '-noncoding sequence was used to generate transgenic mice, which exhibited features of chronic inflammatory polyarthritis (Keffer et al. 1991). In this case, however, transgene TNF $\alpha$ was neither present in the bloodstream nor detected in most cells that normally express TNF $\alpha$. Thus, perhaps not surprisingly, these animals did not develop cachexia, GVHD, necrosis, or most other aberrancies typically associated with TNF $\alpha$ overproduction, and the role of different TNF $\alpha$-producing cells in generating these responses could not be evaluated.

In the present study, we have examined the role of $\mathrm{TNF} \alpha$ produced by keratinocytes. Using a human keratin-14 (K14) promoter, we have overexpressed TNF $\alpha$ in the stratified squamous epithelia of transgenic mice. Surprisingly, the serum levels of TNF $\alpha$ were also greatly elevated in these mice, and the mice displayed numerous morphologic aberrancies, including cachexia, growth inhibition, GVHD-like changes in the skin and, in subsequent phases, intestinal and liver necrosis and death.

\section{Results}

\section{K14-TNF $\alpha$ transgenic mice exhibit cachexia and growth inhibition}

Figure 1A illustrates the keratin promoter-TNF $\alpha$ gene construct used in the generation of transgenic mice. The human K14 promoter has been shown previously to drive expression of reporter transgenes in keratinocytes (Vassar et al. 1989; Vassar and Fuchs 1991; Turksen et al. 1992). The strategy of removing much of the TNF $\alpha 3^{\prime}-$ noncoding sequence was based on the knowledge that these sequences are involved in a tightly controlled posttranscriptional regulation of TNF $\alpha$ mRNA (Beutler et al. 1986; Han et al. 1990; Keffer et al. 1991). The strategy of introducing human growth hormone $(\mathrm{hGH})$ sequences as an intron-containing 3 '-noncoding segment-polyadenylation signal was used previously as a necessary measure to generate appreciable levels of TGF $\alpha$ mRNAs in transgenic mice (Sandgren et al. 1990). Ten founder mice tested positive for the transgene, as judged by polymerase chain reaction (PCR) analysis of their ear DNAs.

Of founders harboring the K14-TNF $\alpha$ transgene, all showed morphologic differences distinguishing them from normal mice (Fig. 1B). Similar to rats injected subcutaneously with TNF $\alpha(0.5 \mu \mathrm{g} / \mathrm{g}$ of body weight per day) (Fong et al. 1989), these transgenic mice were markedly underweight, becoming very frail, exhibiting signs of impaired movement, and wasting within 2-3 weeks after birth. In addition, transgenic mice displayed marked skin abnormalities, with notably thinner skin, revealing the underlying internal organs (Fig. 1C). Through the skin, the intestine of the TNF $\alpha 2$ mouse appeared blackened, suggestive of necrosis (see arrow). This was confirmed after sacrifice and dissection.
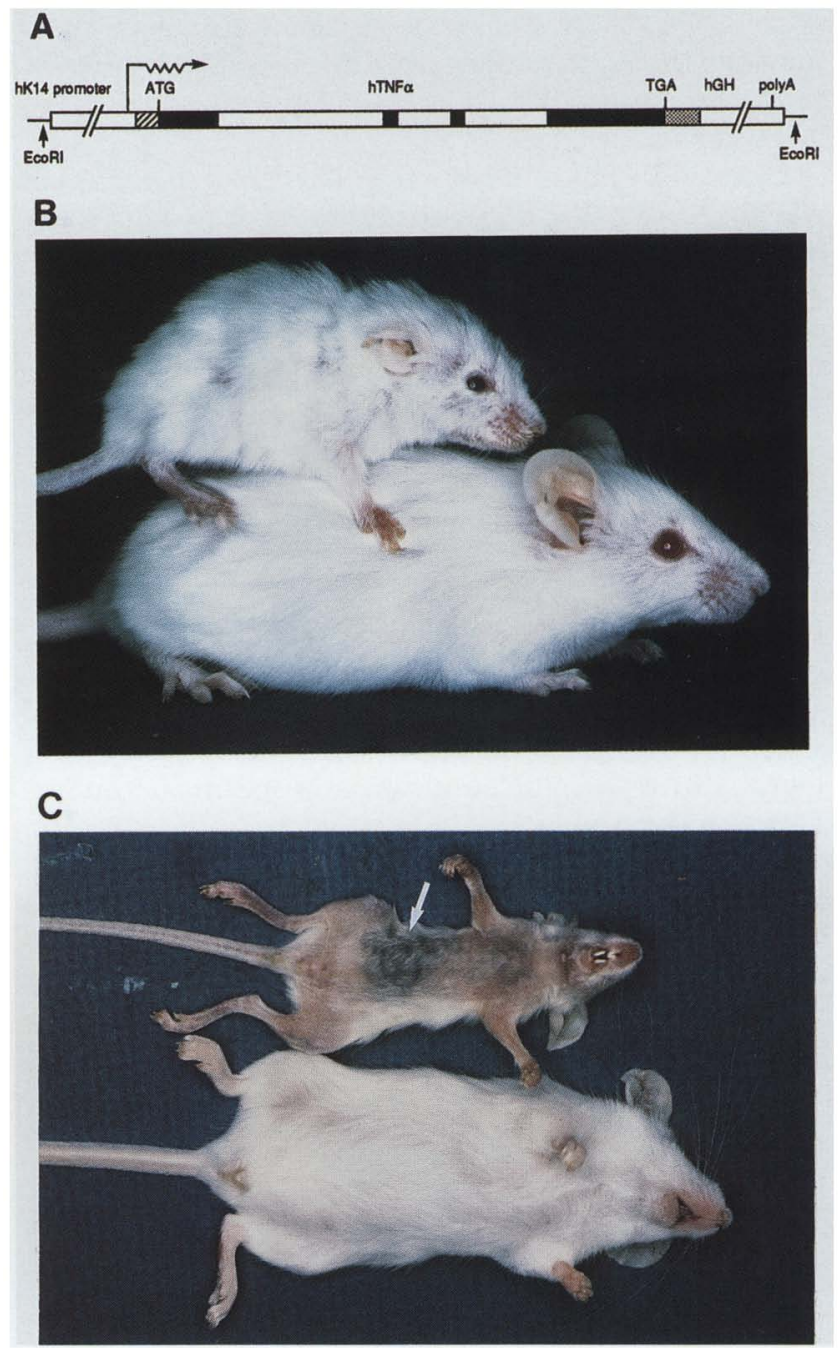

Figure 1. Transgene construct and K14-TNF $\alpha$ transgenic mice. (A) A human $\mathrm{K} 14(\mathrm{hK} 14)-\mathrm{GH}$ expression vector was prepared by (1) cloning $2100 \mathrm{bp}$ of 5 ' upstream sequence (promoter/ enhancer) of the human K14 gene into the AvaI site of plasmid pGEM-3Z (Vassar et al. 1989), and (2) inserting as $3^{\prime}$ noncoding sequence the BamHI-EcoRI fragment containing most of the hGH gene and polyadenylation signal (Sandgren et al. 1990) into the $X b a I$ site of the plasmid. This left an internal BamHI site for cloning in a $2.1-\mathrm{kb}$ AhaII-HindIII partial restriction digestion fragment containing sequences extending from 90 nucleotides $5^{\prime}$ from the ATG start codon of the hTNFo gene (Oliff et al. $1987)$ to 125 nucleotides 3' downstream from the TGA stop codon of the gene. The transgene was excised with EcoRI. (B) A 4-week-old TNF $\alpha$ mouse (TNF $\alpha$ 1) atop a control littermate. (C) A 26-day-old transgenic TNF $\alpha$ mouse (TNF $\alpha$ 2) (top) compared with a control littermate (bottom). Note that typical of older transgenic TNF $\alpha$ animals, mouse TNF $\alpha 2$ was chronically ill, and showed signs of internal hemorrhaging and intestinal necrosis (see arrow).

Transgenic animals began exhibiting abnormalities by 4-6 days of age. Deviations in weight between transgenic mice and their control littermates were observed at this time and increased markedly during neonatal devel- 
opment (Fig. 2). By 20 days of age, some animals were as much as threefold underweight. Most of these mice became chronically ill and either died or were sacrificed by 3-4 weeks of age.

The slender physique of our TNF $\alpha$ transgenic animals was suggestive that these mice may have an adipose deficiency. No intrascapular, perirenal, or subcutaneous fat was seen in any of these mice (data not shown). Collectively, the macroscopic evidence from visual inspection and dissection suggested that K14-TNF $\alpha$ mice had developed cachexia as well as cutaneous and intestinal derangements.

\section{Transgenic human TNF $\alpha$ is present in stratified squamous epithelia and in serum}

To examine how the macroscopic abnormalities correlated with TNF $\alpha$ transgene expression, we isolated organ mRNAs from 6-day-old transgenic and control mice and tested for the presence of transgene mRNAs by PCR analysis with oligonucleotide primers specific for human TNF $\alpha$ (hTNF $\alpha$ ) (Fig. 3A). Relative to mouse $\beta$-actin mRNA expression, brain, heart, lung, liver, kidney, spleen, muscle, and intestine were judged negative for hTNF $\alpha$ mRNA expression. In contrast, transgenic tissues that contain keratinocytes, such as skin, thymus, forestomach, and tongue, were positive for the diagnostic transgene band. In all cases, control tissue mRNAs from a nontransgenic littermate were negative (not shown). In addition, identical results were obtained

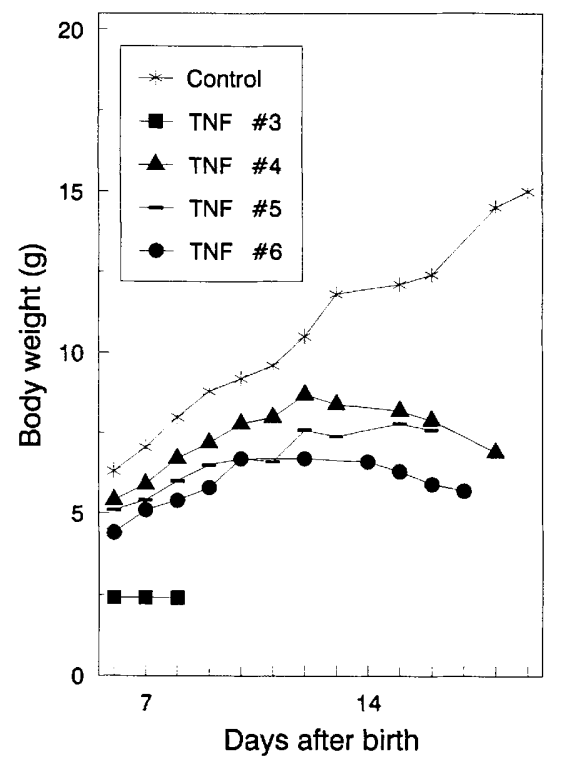

Figure 2. Growth rates of TNF $\alpha$ transgenic mice. TNF $\alpha$ and control littermates were weighed daily, beginning at day 5 when size differences first appeared, and ending at the day they were sacrificed for analyses. Data on four founder mice are shown. Body weights are given in grams. To verify the accuracy of the values for the nontransgenic control, four additional mice were weighed, and growth plots similar to the one shown were achieved.

\section{A}
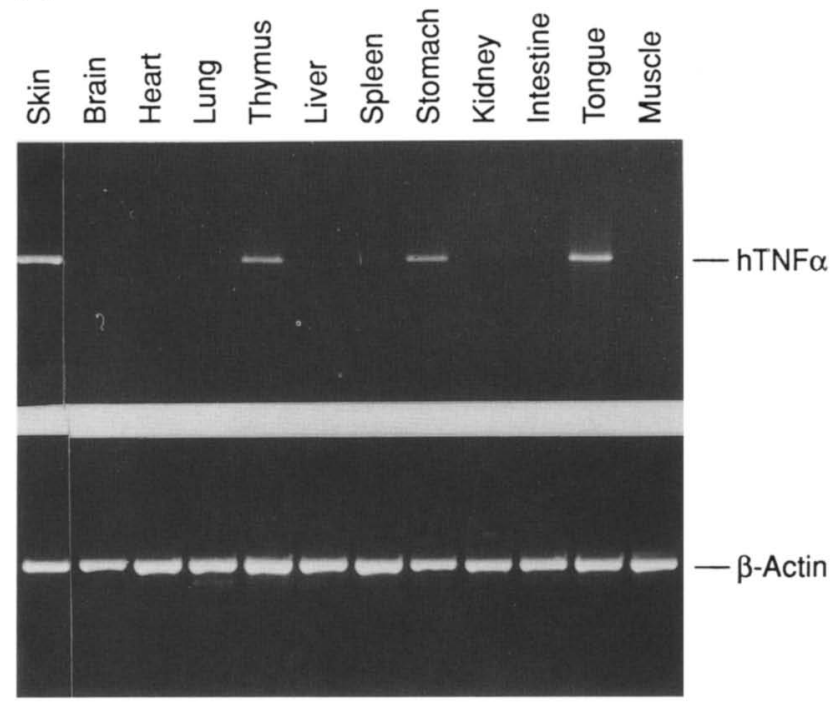

B
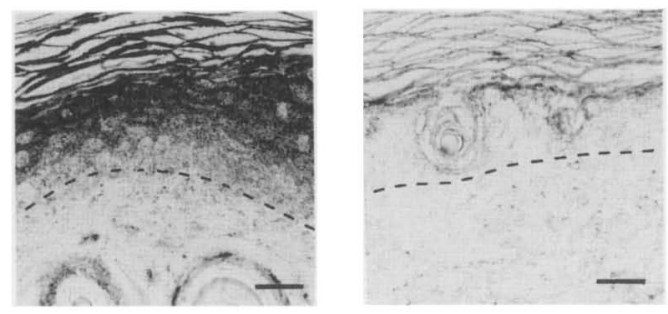

Figure 3. PCR and immunohistochemistry analysis of human TNF $\alpha$ expression in transgenic tissues. (A) PCR analysis. PCR products from transgenic and control organ mRNAs were resolved by electrophoresis and visualized by staining with ethidium bromide (see Materials and methods). Shown here are data from a set of RNAs from one of the two transgenic animals analyzed. Both animals gave identical results with respect to tissue specificity of transgene expression. As expected, none of the control littermate samples produced any PCR products with the primers for hTNF $\alpha$, and all samples gave signals of comparable intensity with the primers for mouse $\beta$-actin. $(B)$ Immunohistochemistry. To verify transgene expression, skin samples of transgenic and control mice were fixed in $2 \%$ paraformaldehyde, embedded in paraffin, sectioned $(5 \mu \mathrm{m})$, and stained with an antiserum specific for hTNF $\alpha$ (Genzyme, Boston, MA). The antibody-staining procedure was immunogold enhancement, described previously (Vassar et al. 1989). (Left) TNF $\alpha$ transgenic mouse skin; (right) skin from a control littermate. Broken lines denote demarcation between epidermis and dermis. Bars, 15 $\mu \mathrm{m}$

when tissue mRNAs from a second transgenic mouse and control littermate were analyzed. The pattern of expression of the transgene was in agreement with the known pattern of expression of both the human K14 promoter and the endogenous mouse K14 in these tissues (Nelson and Sun 1983; Vassar et al. 1989; S. Zinkel and E. Fuchs, unpubl.). To verify that stable hTNF $\alpha$ protein 
was produced in keratinocytes, we used an anti-hTNF $\alpha$ antibody to stain tissue sections. As expected, antihTNFo staining was detected in the epidermis and hair follicles of transgenic skin, but not control skin (Fig. 3B).

The absence of fat and the presence of intestinal necrosis and cachexia in our TNF $\alpha$ transgenic animals were consistent with the known effects of elevated serum levels of TNF $\alpha$, but they were not consistent with a keratinocyte-restricted expression pattern of the transgene. Therefore, we tested the possibility that TNF $\alpha$ was present in the bloodstream of our transgenic mice. The amount of TNF $\alpha$ was quantified by adding serial dilutions of serum samples to TNF $\alpha$-sensitive 1591-RE3.5 cells and analyzing the effect on viable cell numbers with a colorimetric assay (Teng et al. 1991). As illustrated in Figure 4 (left), transgenic but not control serum contained high levels of TNF $\alpha$. The majority of this could be neutralized with a mouse monoclonal antibody specific for human TNF $\alpha$ (Fig. 4, right). In contrast, little or no neutralization was obtained with an anti-mouse TNF $\alpha$ antiserum (not shown). That proteins produced and secreted by epidermal cells can enter into the bloodstream has been demonstrated previously (Fenjves et al.

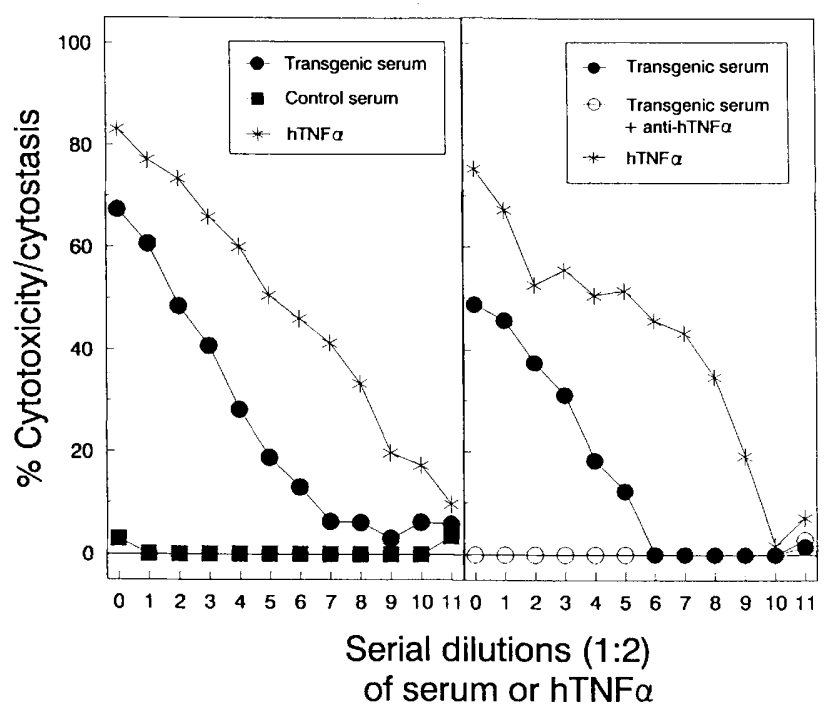

Figure 4. Detection of biologically active hTNF $\alpha$ in the serum of transgenic mice. (Left) Sera from transgenic and control littermates were assayed as outlined in Materials and methods. Serum levels of biologically active TNF $\alpha$ were measured by examining serum-induced cytotoxicity of an extremely TNF $\alpha$ sensitive murine skin tumor cell line, 1591-RE3.5. Cytotoxicity-cytostasis was measured by dye uptake of degenerating cells (see Materials and methods). Test runs were made with serial dilutions of serum from a TNF $\alpha$ transgenic mouse (TNF $\alpha 1)$ and a control littermate. Serial dilutions of recombinant hTNF $\alpha(5$ $\mathrm{U} / \mathrm{ml} ; 100 \mathrm{pg} / \mathrm{ml}$ ) were used as standards. (Right) The experiment shown at left was repeated, this time using serum from TNF $\alpha$ mouse 1, either in combination with or without added mouse monoclonal antibody specific for hTNF $\alpha$. Note that the anti-hTNF $\alpha$ antibody neutralized the TNF $\alpha$ activity, indicating that the majority of the serum TNF $\alpha$ was human (i.e., transgene), rather than mouse (i.e., endogenous).
1989; Teumer et al. 1990), but this was not observed when the same K14 promoter-enhancer was used to drive the expression of TGF $\alpha$ or interleukin 6 (IL-6) mRNAs tagged with the hGH gene segment as 3 '-noncoding sequences (Vassar and Fuchs 1991; Turksen et al. 1992). It seems unlikely that these differences arose solely from differences in sensitivities of the serum assays used to detect different factors, because TNF $\alpha$ was the only one of these three factors to show systemic effects on nonkeratinocyte-containing tissues. Furthermore, it is unlikely that the blood TNF $\alpha$ was derived from hitherto unrecognized regulatory sequences downstream from the transcription initiation site of the hTNF $\alpha$ gene, as a different promoter was recently used to express this same gene in transgenic mice, and yet these mice did not have appreciable levels of TNF $\alpha$ in their blood (Keffer et al. 1991). Collectively, these observations suggest that the presence of TNF $\alpha$ in the bloodstream of our transgenic animals came from the tissue specificity provided by the K14 promoter.

TNF $\alpha$ overexpression leads to a myriad changes in the skin, particularly in the dermis and subcutaneous fat

Histopathologic examination of Bouin's fixed and hematoxylin- and eosin-stained sections of skin from 6-dayold hTNF $\alpha$-expressing and nontransgenic animals did not reveal major differences in the epidermis at this early age (Fig. 5A, transgenic skin; Fig. 5B, control skin). Transgenic basal cells appeared a bit flatter and sometimes smaller than normal, however, and the stratum corneum appeared somewhat thicker than normal. These differences did not seem to cause changes in the biochemical program of terminal differentiation, as judged by immunohistochemistry staining with anti$\mathrm{K} 14$, anti-K1, and anti-filaggrin antibodies (data not shown).

Although TNF $\alpha$ was made by keratinocytes, the major changes in the skin of 6-day-old transgenic animals appeared to be in the tissue underlying the epidermis (Fig. $5 \mathrm{C}$, glutaraldehyde- and paraformaldehyde-fixed semithin section of transgenic skin; Fig. 5D, analogous section of control skin). Most notably, there was a striking difference in the relative amounts of underlying fat. This is in agreement with the known influence of TNFo in inhibiting fat production (Torti et al. 1985; Stephens and Pekala 1991). The reduction in fat was paralleled by an increase in thickness and cellularity of the dermis (cf. Fig. 5C and D). This increase, however, was not sufficient to overcome the reduction in subcutaneous fat, leaving a shortening (approximately twofold) of the distance between the muscle and the epidermis. Consequently, hair follicles were substantially shorter than normal, and their shape was often distorted at the base of the muscle layer (see Fig. 5C). In addition, the density of hair follicles was greater than that of a control littermate. The difference in hair follicle density was likely to be, in part, a consequence of the overall growth retardation of TNF $\alpha$-expressing mice, as differences in follicle density waned at later ages and as it is well-known that 

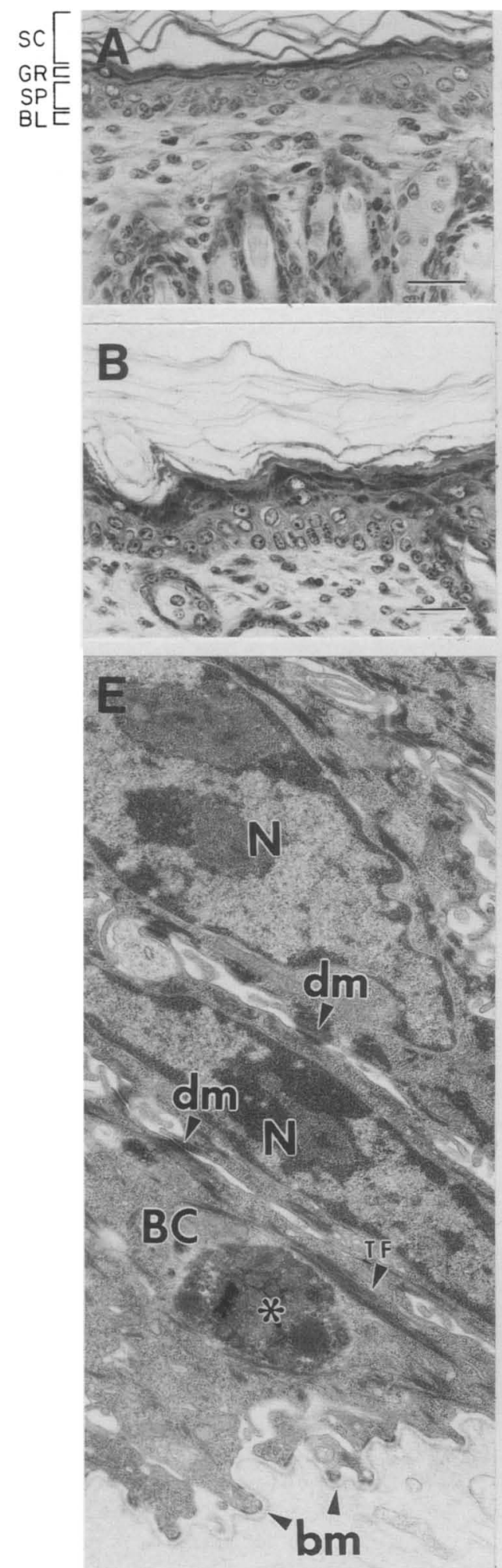
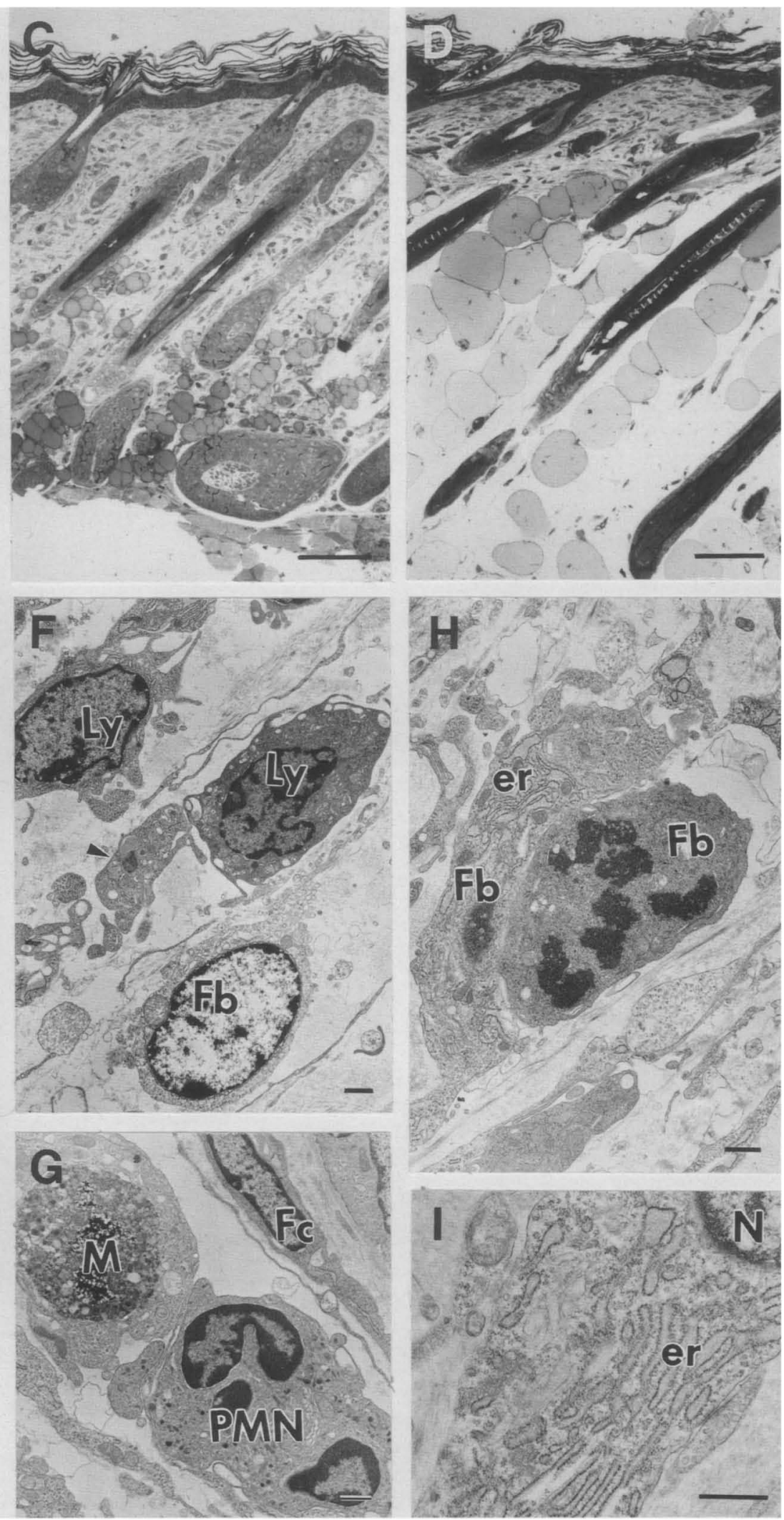
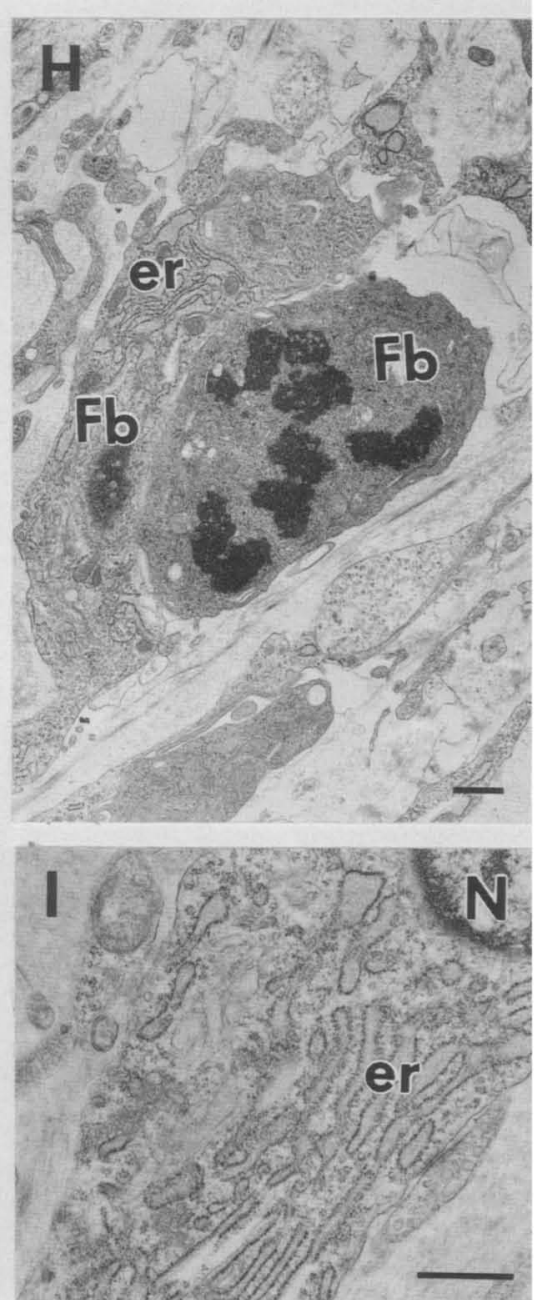

Figure 5. (See facing page for legend.) 
hair follicle numbers are fixed by birth and diluted naturally during neonatal development. It is notable, however, that TNF $\alpha$ has been found previously to elicit effects on hair growth, particularly when produced in the brain (Cerami 1992).

To further explore differences in transgenic and control skin, we examined their ultrastructure (Fig. $5 \mathrm{E}-\mathrm{H}$ ). Although many transgenic epidermal cells appeared indistinguishable from control cells, there was evidence of isolated degeneration in some basal cells (Fig. 5E, asterisk). Cell debris was also quite prominent in the dermis, where there was an infiltration of macrophages, polymorphonuclear neutrophils, and eosinophils, as well as an increased number of lymphocytes (Fig. 5F, G; lymphocytes and macrophage engulfing a degenerated cell; polymorphonuclear neutrophil). Although our light microscopy studies indicated that the leukocytic infiltration was not massive, the ultrastructural studies clearly revealed an increase in leukocytes in transgenic versus control skin. Furthermore, our results are in agreement with a number of recombinant TNF $\alpha$ studies demonstrating that this factor, directly, indirectly, or synergistically, promotes chemotaxis and antimicrobial activity of neutrophils, macrophages, and eosinophils (Rothstein and Schreiber 1988; Sharpe et al. 1988; Tracey et al. 1988; Munro et al. 1989; Rampart et al. 1989).

In addition to the changes in dermal leukocyte populations, dermal fibroblasts were also increased in number. A localized increase in fibroblast numbers was also observed previously, when recombinant TNF $\alpha$ was subcutaneously injected into mice /Vilcek et al. 1986; Sharpe et al. 1988; Piguet et al. 1990; Postlethwaite and Seyer 1990). The fibroblasts appeared unusually active, with many undergoing mitosis, and the majority exhibiting an enriched endoplasmic reticulum, suggestive of collagen synthesis (Fig. 5H, top: fibroblast at right undergoing mitosis; fibroblast at left with abundant endoplasmic reticulum; Fig. $5 \mathrm{H}$, bottom: portion of a fibroblast cytoplasm at higher magnification to show greater details of rich endoplasmic reticulum).

Despite the general stimulation of fibroblast growth in the dermis of transgenic skin, some signs of fibroblast degeneration were evident that were not seen in control skin (Fig. 5F,G). These observations suggested that TNF $\alpha$ overexpression by epidermal cells caused both positive and negative effects on fibroblast growth and differentiation. In this regard, it is interesting that although recombinant TNF $\alpha$ injections have revealed signs of elevated collagen levels (Piguet et al. 1990), the effects of recombinant TNF $\alpha$ on collagen synthesis in vitro have been negative (Brenner et al. 1989). It remains to be investigated whether the ability of TNF $\alpha$ to elicit both positive and negative effects on fibroblasts is reflective of (1) differences between primary versus secondary responses to TNF $\alpha$ and the factors it induces, (2) differences in overall TNF $\alpha$ levels, or (3) differences between the direct effects of TNF $\alpha$ on fibroblasts versus indirect effects on fibroblasts exerted by other cell types within the skin that are influenced by TNF $\alpha$.

The TNF $\alpha$-mediated skin changes described above were even more pronounced in mice as they grew older. By 2-4 weeks of age, transgenic epidermis was notably thinner than the control, and cells showed signs of hypotrophy (Fig. 6A, transgenic; Fig. 6B, control). Conversely, the stratum corneum was markedly thickened. Whether stratum corneum thickening was the result of a factor-mediated enhancement of the terminal differentiation program or, alternatively, an increase in squame adhesiveness remains to be evaluated. It was interesting, however, that the stratum corneum was also increased in the epidermis of transgenic animals overexpressing IL- 6 driven off the same K14 promoter (Turksen et al. 1992).

By 14 days, signs of fat production were nearly absent in TNF $\alpha$ skin (Fig. 6, cf. C and D), and the distance between the epidermis and the muscle had declined by approximately five- to sixfold, leaving the hair follicles significantly shortened. Surprisingly, surface hair length was not markedly reduced from control animals. However, the hair coat still appeared to be less dense than normal, suggesting that the growth of some follicles may have been retarded. Presumably, the deeper follicles were the ones affected, because their structures were perturbed by the shortened distance between the epidermis and the underlying muscle.

Additional skin differences were evident at the ultrastructural level. In some regions, the epidermis was remarkably thin, with only a single layer of spinous cells

Figure 5. Histopathology and electron microscopy of skin changes in 6-day-old TNF $\alpha$ transgenic mice. $(A, B)$ Backskin samples $(2$ $\mathrm{mm}^{2}$ ) from 6-day-old transgenic and control mice were fixed, and paraffin-embedded sections (5 $\left.\mu \mathrm{m}\right)$ were stained with hematoxylin and eosin. (A) TNF $\alpha$ transgenic mouse; $(B)$ control mouse. Bars, $(A, B) 15 \mu \mathrm{m}$. (BL) Basal layer; (SP) spinous layers; (GR) granular layers; (SC) stratum corneum. $(C, D)$ Semithin sections $(0.75 \mu \mathrm{m})$ of epoxy resin-embedded skin samples were stained with toluidine blue for light microscopy. $(C)$ TNF $\alpha$ transgenic mouse; $(D)$ control mouse. Note the difference in dermal thickness between transgenic $(C)$ and control $(D)$ mice. [The bottom of the photo shown in $C$ is nearly at the bottom of the dermis.] Bars, $(C, D) 35 \mu \mathrm{m}$. $(E-H)$ For electron microscopy, transgenic backskin samples were fixed and processed as described in the Materials and methods. $(E)$ Basal epidermal layer, illustrating unusually thin basal cell (middle of the three cells) and occasional degenerating cell (bottom cell; necrosis denoted by asterisk). (Cell at top is barely attached to the basement membrane.) (N) Nucleus; (dm) desmosomes; (BC) basal cell; (bm) basement membrane; (TF) tonofilaments. $(F-H)$ Dermis, illustrating infiltration of lymphocytes (Ly). $(F)$ Polymorphonuclear neutrophils (PMN) and activated macrophages $(\mathrm{M})$. (Fc) Fibrocyte. $(G)$. In addition, although a few fibroblasts (Fb) showed signs of degeneration (e.g., cell in $F)$, many fibroblasts appeared highly active, with enriched endoplasmic reticulum (er), numerous filopodia and frequent mitoses $(H$, top, two adjacent fibroblasts; one is undergoing mitosis. Bottom, higher magnification of fibroblast cytoplasm, revealing extensive endoplasmic reticulum). Bars $(E-H) 1 \mu \mathrm{m}$. 
Cheng et al.
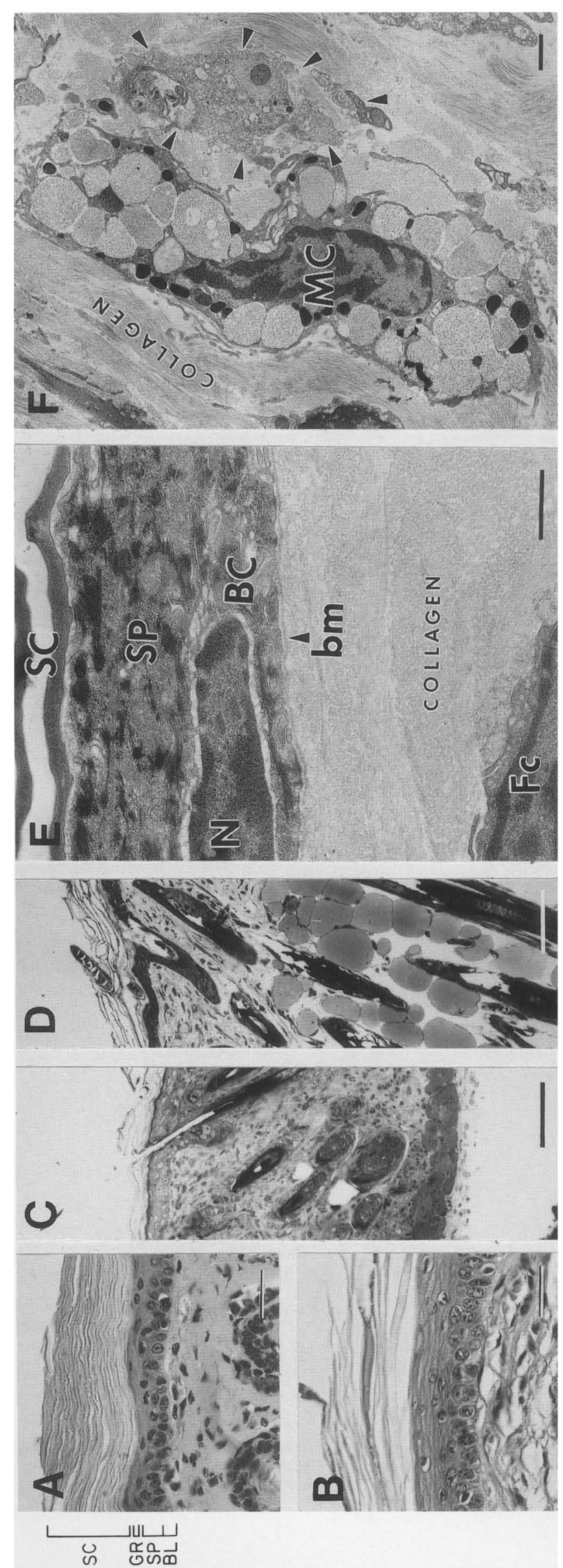

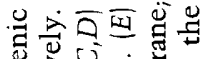

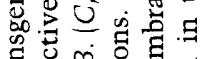

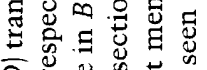

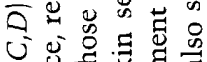

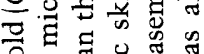

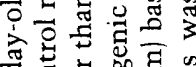

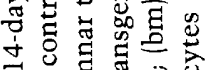

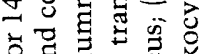

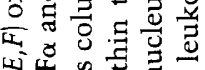

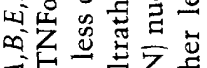

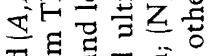

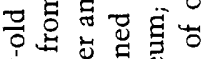

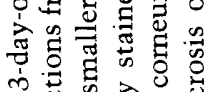

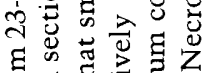
घ

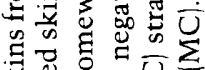

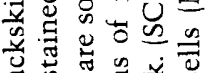

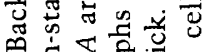

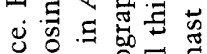
घี

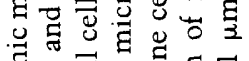

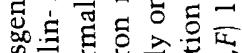

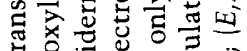

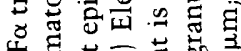

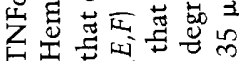

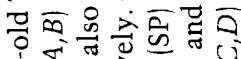
苟 3 in $z$ 更要

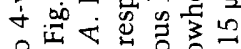
의

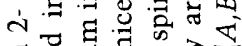

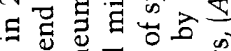

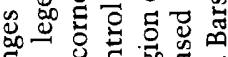

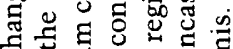
일

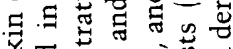

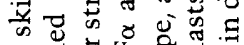

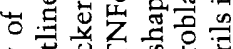

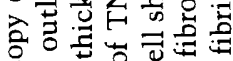
of 0 它 讨

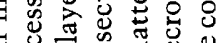

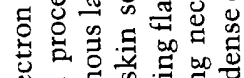

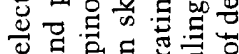

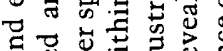

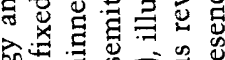

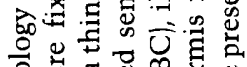

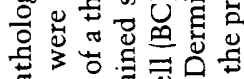

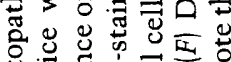

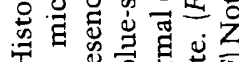

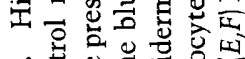

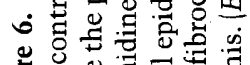

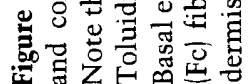


(Fig. 6E, SP). As seen to a lesser extent in younger transgenic animals, basal cells often appeared flattened, and occasional epidermal necroses were seen (not shown). The density of collagen in the dermis was even more pronounced than observed at the younger ages. Although this was also seen at the light microscopy level (Fig. 6, cf. $A$ and $B$ ), it was striking at the ultrastructural level (Fig. $6 E)$. In addition, although the cellularity of the dermis was not as prominent as before, dermal necroses were significantly more prevalent than seen previously. This extended to most types of leukocytes as well as fibroblasts. Interestingly, whereas mast cells in the skin of transgenic animals at day 6 exhibited many granules, these cells contained predominantly empty granules at later ages (Fig. 6F). Necrosis of macrophages and lymphocytes provided additional signs that the immune system was compromised in the older TNF $\alpha$-expressing mice.

The extensive degeneration in the skin of older TNF $\alpha$ expressing mice was similar to the response elicited during GVHD, where TNF $\alpha$ levels are known to be elevated dramatically in the skin (Sale et al. 1985; Piguet et al. 1987). The fact that the onset of major cell degeneration was delayed relative to the timing of hTNF $\alpha$ expression was suggestive that these changes were either dependent on prolonged constitutive TNF $\alpha$ expression or that man- ifestation of massive cell degeneration required a series of secondary steps subsequent to TNF $\alpha$ expression.

\section{TNF $\alpha$-mediated effects on cell growth in the epidermis and dermis as seen by bromodeoxyuridine labeling}

When cultured epidermal keratinocytes are treated with nanomolar concentrations of recombinant $\mathrm{TNF} \alpha$, their growth is profoundly inhibited (Pillai et al. 1989; Symington 1989; J. Cheng and E. Fuchs, unpubl.). The thinness of the epidermis in some of our older TNF $\alpha$ transgenic animals was consistent with the notion that TNF $\alpha$ might also be growth inhibitory to keratinocytes in vivo. To assess whether TNF $\alpha$ expression may also influence epidermal growth in vivo at earlier ages, we incubated samples of transgenic and control skin in medium containing $40 \mu \mathrm{M}$ bromodeoxyuridine (BrdU). Anti-BrdU staining of paraformaldehyde-fixed skin sections revealed only a slight decrease in the total number of DNA-synthesizing cells in the epidermis (Fig. 7A, left). Labeling in control skin, however, was more uniform than in transgenic skin (anti-BrdU-stained sections, Fig. $7 \mathrm{~B}$, left and right, respectively). Thus, most regions of transgenic skin exhibited only a few stained basal cells,
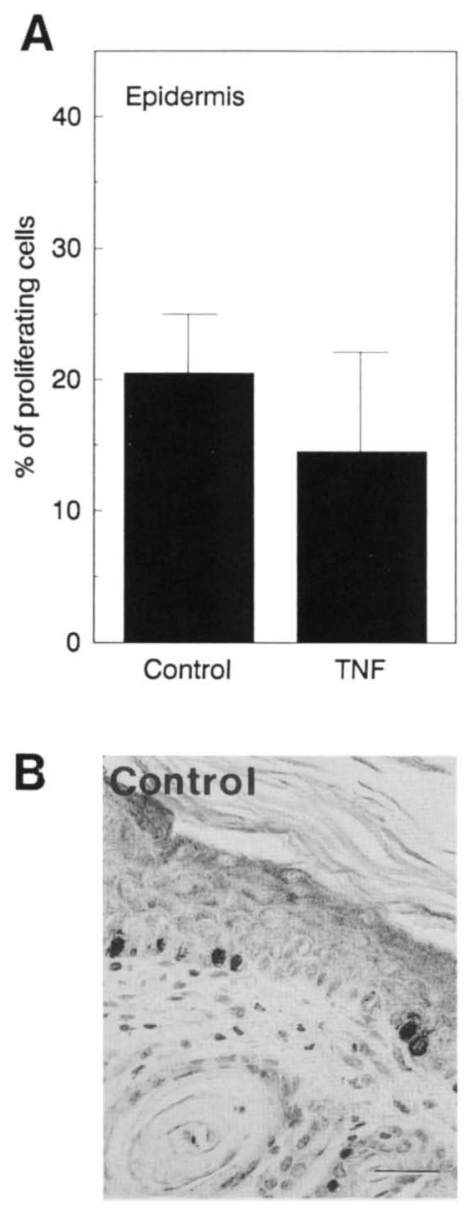
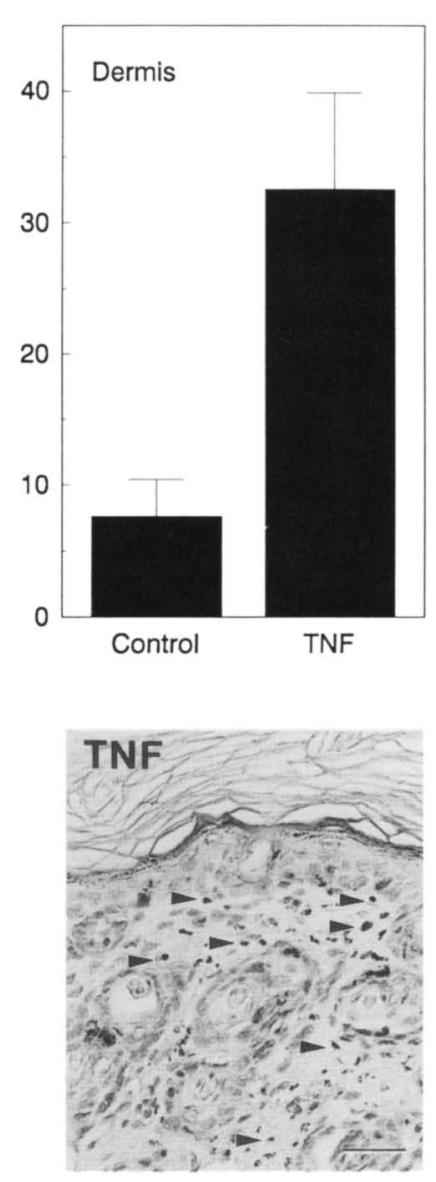

Figure 7. Changes in the number of DNA synthesizing epidermal and dermal cells in TNF $\alpha$ transgenic mice. Samples of skin $(1 \times 2 \mathrm{~mm})$ from 8-day-old TNFo transgenic and control mice were placed for $4 \mathrm{hr}$ in medium containing $40 \mu \mathrm{M}$ BrdU. Samples were washed, fixed in $2 \%$ paraformaldehyde, and sectioned, followed by staining with an anti-BrdU antibody, immunogold labeling, and silver enhancement (Vassar and Fuchs 1991). (A) The percentages of labeled cells per unit area of the basal epidermal layer (left) and the dermis (right) were estimated by counting labeled and unlabeled cells in photographs from 10 random fields. Levels of significance for comparisons between samples were determined using the twotailed Student's $t$-test. Statview software was used to calculate mean and standard deviations. $(B)$ Representative examples of the BrdU labeling of skin from control (left) and transgenic (right) mice are also shown. Arrowheads denote labeled cells. Bar, $15 \mu \mathrm{m}$. 
with the majority of labeling concentrated in a few isolated regions. These patches of labeling might have been caused by local proliferation induced by the observed patchiness in necroses that occurred within the epidermis. If so, this effect might have tempered somewhat the degree to which TNF $\alpha$ might have actually inhibited keratinocyte growth. This would also explain why Piguet et al. (1990) observed a localized hyperplastic response when mice were injected subcutaneously with TNF $\alpha$ at sufficiently high concentrations to cause substantial epidermal necroses. The patchiness in necrosis may be a further indication that necrosis arises from the synergistic effects of $\mathrm{TNF} \alpha$ with other factors, including those that are bacterially derived (Rothstein and Schreiber 1988; Schreiber et al. 1990).

In contrast to its inhibitory effects on epidermal keratinocytes, TNF $\alpha$ has both proliferative /Vilcek et al. 1986; Piguet et al. 1990) and chemoattractive (Postlethwaite and Seyer 1990) effects on fibroblasts. Transgenic dermis showed an increase in the density of BrdU-labeled cells (Fig. 7A, right; cf. labeling in the dermis of anti-BrdU-stained sections in Fig. 7B). Most of the DNAsynthesizing cells in the dermis were fibroblasts (arrowheads denote labeled cells), and this increase in labeling was consistent with the proliferative and chemoattractive effects of $\mathrm{TNF} \alpha$ and with the enhanced cellularity within the dermis.

\section{Induction of mouse TNF $\alpha, I L-6$, and IL-1 mRNAs in $h T N F \alpha$ transgenic skin}

$\mathrm{TNF} \alpha$ is known to activate a wide variety of genes in a multitude of target cells (Fong et al. 1989; Akira et al. 1990; Cerami 1992). This includes an autoinduction process as well as an induction of IL- 6 and interleukin 1 (IL-1). To determine whether these factors are induced in our mice as a consequence of transgene TNF $\alpha$ expression, we isolated skin mRNAs from transgenic and control mice and subjected 500-ng RNA aliquots to PCR analyses using oligonucleotide primers specific for mouse TNF $\alpha$, IL-6, and IL- $1 \alpha$ mRNAs (Fig. 8). As expected, control oligonucleotide primers specific for mouse $\beta$-actin and mouse K14 gave rise to PCR cDNAs of the expected sizes for both transgenic and control skin mRNAs. In contrast, oligonucleotide primers specific for mouse TNF $\alpha$ mRNA generated an intense PCR band of the expected size in the transgenic, but not the control, skin sample. That mouse TNF $\alpha$ mRNA was induced in keratinocytes was confirmed by selectively removing the epidermis from the skin and repeating the mRNA extraction and PCR analyses (not shown). Despite the ability of endogenous TNF $\alpha$ mRNA to be induced in hTNF $\alpha$-expressing transgenic keratinocytes, most of the active TNF $\alpha$ produced by these mice appeared to be hTNF $\alpha$ (transgene), as distinguished by the species-specific antibodies used in the blood serum assays (see Fig. 4).

We were struck by the morphologic similarities in the epidermis of 3- to 4-week-old transgenic animals expressing TNF $\alpha$ (this paper) and IL-6 (Turksen et al. 1992) driven off the K14 promoter-enhancer. To assess whether IL-6 might be induced in the skin of transgenic mice, we repeated the PCR analyses, this time with oligonucleotide primers specific for mouse IL-6. As illustrated in Figure 8, an IL-6 PCR band of the appropriate size was present in the transgenic, but not the control, skin sample. Again, IL-6 mRNAs were induced in the keratinocyte fraction of the skin, as judged by epidermal fractionation (not shown). Thus, our findings are consistent with the notion that some of the changes in the epidermis may be the result of induction of IL- 6 gene expression by TNF $\alpha$.

Another factor known to be up-regulated with treatment of epidermal cells with TNF $\alpha$ is IL- $1 \alpha$ (for review, see Akira et al. 1990). IL-1 was discovered as a pyrogen, and it is the most potent inflammatory cytokine that can generate prostaglandin $E_{2}$ synthesis and become chemotactic and mitogenic for thymocytes, lymphocytes, and
Figure 8. Induction of mTNF $\alpha$, IL- 6 and IL-1 mRNAs in skin of TNF $\alpha$-expressing transgenic mice. Total equal amounts of RNAs (5 $\mu \mathrm{g}$ each) from skins of transgenic and control animals were subjected to PCR analyses, using the oligonucleotide primers specific for mRNAs encoding mouse $\beta$-actin, mouse $\mathrm{K} 14$, hTNF $\alpha$ (transgene), mTNF $\alpha$, mouse IL-6, and mouse IL-1. PCR products were resolved by electrophoresis through $2 \%$ agarose gels. The experiments were run in duplicate with the controls outlined in Materials and methods. (Left) Numbers indicate sizes in base pairs of DNA molecular mass standards. The protein and cytokine for which the primer set is specific is indicated at the top. (Lanes 1) The data from the transgenic sample; (lanes 2) the control skin sample. The data obtained for all PCR reactions except IL $1-\beta$ were similar when mRNAs were used from epidermises that were separated from the rest of the skin by sodium bromide treatment (not shown; see Materials and methods).

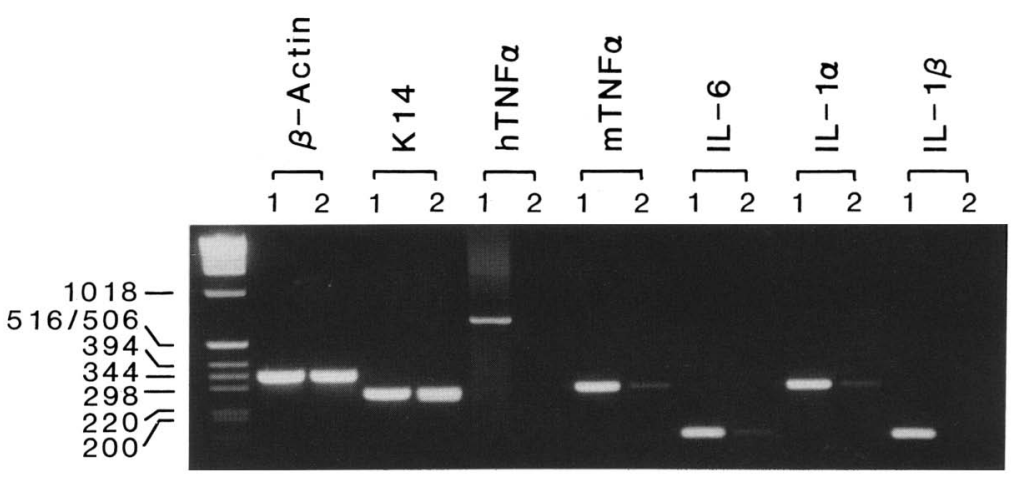


other immune cells. A strong PCR band was seen in the keratinocyte mRNA fraction of transgenic, but not control, skin, suggesting the possibility that IL- $1 \alpha$ may play a role in mediating a part of the inflammatory response seen in our TNF $\alpha$ mice. IL-1 $\beta$ mRNA was also induced in TNF $\alpha$ mice, but this appeared to be largely in the dermal component of the fractionated skin. Additional studies will be necessary to determine the extent to which other cytokines and factors, including interleukin 8 (IL-8), transforming growth factor- $\beta$ (TGF- $\beta$ ), and granulocyte macrophage-colony-stimulating factor $(\mathrm{GM}-$ CSF), might be relevant to the wide range of pleiotropic effects observed in our mice, both in the skin and in other organs.

\section{Discussion \\ Keratinocyte-expressed TNF $\alpha$ appears to play a major role in eliciting the pleiotropic effects of TNF $\alpha$}

The TNF $\alpha$-expressing transgenic mice that we have generated using a keratinocyte promoter and an altered 3'noncoding segment had a markedly different phenotype from those generated previously by use of the natural TNF $\alpha$ promoter and an altered 3 '-noncoding segment (Keffer et al. 1991). Most notably, although our mice developed weight loss, cachexia, inflammation, keratinization, fibrosis, necrosis, and intravascular hemorrhaging, the previous TNF $\alpha$ transgenic mice only developed one feature typically associated with high levels of TNF $\alpha$, namely chronic inflammatory polyarthritis. The obvious explanation for these differences is the targeting of deregulated TNF $\alpha$ expression to different tissues. Keffer et al. (1991) detected transgene mRNAs primarily in thymus, lung, spleen, kidney, brain, joints and possibly, skin, but these mice did not produce appreciable serum levels of transgene TNF $\alpha$. In contrast, we targeted TNF $\alpha$ transgene expression to tissues containing keratinocytes, and these mice readily produced detectable serum levels of transgene TNF $\alpha$.

Our findings have important implications for the role of TNF $\alpha$-expressing keratinocytes in inflammatory and immune responses in mammals. Prior to our studies, it had been widely assumed that macrophages were the major mediators of TNF $\alpha$ action. Although macrophages may still play a seminal role in exerting the TNF $\alpha$-induced immune responses, our studies suggest that other $\mathrm{TNF} \alpha$-producing cells, such as keratinocytes, can also mediate a chemotactic recruitment of macrophages, polymorphonuclear neutrophils, and eosinophils to the skin. Our mice exhibited most, if not all, of the effects known to be characteristic of TNF $\alpha$. We have not unequivocally ruled out the possibility that expression of the transgene by nonkeratinocyte cells could have escaped our detection. The major source of transgene TNF $\alpha$ in our mice was the keratinocyte, however, and specifically, the epidermal keratinocyte. Thus, it seems most likely that keratinocyte-derived TNF $\alpha$ was able to find its way into the bloodstream, thereby activating a global response to the immune system of the animal.
Grafting transgenic epidermal keratinocytes to the skin of nude mice, analogous to procedures used by Teumer et al. (1990), should be able to test this hypothesis directly.

\section{Transgene hTNF $\alpha$ leads to up-regulation of endogenous mouse TNF $\alpha$ mRNA levels}

An interesting consequence of our transgene hTNF $\alpha$ expression was the up-regulation of endogenous mouse $\mathrm{TNF} \alpha(\mathrm{mTNF} \alpha)$ mRNA. Although we presented data only for up-regulation of skin mTNF $\alpha$ mRNAs, we noticed that many other transgenic tissues also showed elevated levels of endogenous TNF $\alpha$ mRNAs (data not shown). Because this up-regulation in mTNF $\alpha$ mRNA levels occurred irrespective of whether the tissue contained keratinocytes, much of the induction may have been a consequence of circulating hTNF $\alpha$. In this regard, it was curious that the TNF $\alpha$ present in the blood was mostly human, as judged by neutralization of the activity with antibodies that were highly specific for hTNF. It is well-known, however, that TNF $\alpha$ has intricate regulatory mechanisms at post-transcriptional levels. Thus, it was shown previously that after activation of TNF mRNA translation by lipopolysaccharide (a major inducer of inflammation), transcription from the TNF $\alpha$ gene is augmented three times, whereas steady-state TNF mRNA levels are increased $\geqslant 100$ times (Beutler et al. 1986; Han et al. 1990). Moreover, when the hTNF $\alpha$ transgene was recently introduced into the germ line of mice, no apparent phenotype was detected, although $h T N F \alpha$ mRNAs were produced in a number of different tissues (Keffer et al. 1991). In contrast, a TNF $\alpha$ mRNA with a modified 3 '-noncoding sequence was deregulated, and biologically active TNF $\alpha$ was produced (Keffer et al. 1991), perhaps in a fashion similar to our TNF $\alpha$ mRNA, which had extended hGH sequences in place of the natural 3'-noncoding sequence. These differences could readily account for our failure to detect appreciable mTNF $\alpha$, although the endogenous TNF $\alpha$ mRNA was upregulated quite dramatically. Given the potentially lifethreatening effects of $\mathrm{TNF} \alpha$, intricate regulation is not surprising.

\section{TNF $\alpha$ action: direct vs. indirect effects}

TNF $\alpha$ secretion can be elevated to dangerous levels during severe infections, leading to such deleterious effects as fever, hypotension, acidosis, diffuse intravascular coagulation and, ultimately, death (for review, see Tracey et al. 1986; Schreiber et al. 1990). At lower levels, TNF $\alpha$ plays an important protective role in infectious diseases, stimulating chemotaxis and the antimicrobial activity of neutrophils, macrophages, and eosinophils (Sharpe et al. 1988; Tracey et al. 1988; Munro et al. 1989; Rampart et al. 1989). That TNF $\alpha$ is the mediator of these pleiotropic responses has been demonstrated by neutralizing the effects with anti-TNFo antibodies (Beutler et al. 1985; Piguet et al. 1987; Tracey et al. 1987; Keffer et al. 1991). In addition, administration of sublethal doses of recom- 
binant TNF $\alpha$ to rodents has been shown to cause cachexia, anemia, neutrophil-, eosinophil-, and macrophagemediated inflammation, septic shock during lethal bacteremia, epidermal and dermal necroses similar to GVHD, and hemorrhagic necrosis in certain tumors (Sale et al. 1985; Tracey et al. 1986, 1987, 1988; Oliff et al. 1987; Piguet et al. 1987; Djeu et al. 1988; Rothstein and Schreiber 1988; Gordon and Galli 1990; Teng et al. 1991).

Given the myriad regulatory factors that are influenced by TNF $\alpha$ expression, it is highly likely that TNF $\alpha$ acts in concert with these other cytokines, factors, and inflammatory cells to elicit the varied and extensive macroscopic changes in animal physiology. In this regard, it has been shown that at least in part, the effects of TNF on severe bacterial infections may be the result of a strong synergy between TNF and bacterial substances and other factors which, in turn, may induce other synergistic cytokines (Rothstein and Schreiber 1988). IL-6 is one cytokine that is thought to be a major player in mediating some of the responses of TNF $\alpha$ (for review, see Akira et al. 1990; Cerami 1992). We have recently prepared transgenic mice overexpressing keratinocyte IL-6 (Turksen et al. 1992). The effects on the stratum corneum and hair growth that were elicited by TNF $\alpha$ overexpression seemed similar to those elicited by IL- 6 overexpression. Thus, the effects that we have observed on the epidermis in our TNF $\alpha$ mice might be indirect, arising from IL-6 induction. In contrast, we did not detect an appreciable inflammatory response in our IL- 6 mice, nor did we detect the other major changes in the skin and other organs that were seen in our TNF $\alpha$ mice. Therefore, it seems that these additional features must arise either from other cytokines and factors, or from IL-6 acting synergistically either with TNF $\alpha$ itself or with other induced factors.

The inflammatory responses in the skin could have been mediated by several of the cytokines known to be activated by TNF $\alpha$. Of these, IL-1 was discovered as a pyrogen, and it is the most potent inflammatory cytokine that can generate prostaglandin $\mathrm{E}_{2}$ synthesis and become chemotactic and mitogenic for thymocytes, lymphocytes, and other immune cells (Fong et al. 1989; Akira et al. 1990; Cerami 1992). This factor is expressed in keratinocytes and dermal endothelial cells in response to $\mathrm{TNF} \alpha$, and it provides adhesion sites for neutrophils and lymphocytes (Griffiths et al. 1989). In our studies, IL- $1 \alpha$ was found preferentially in the epidermis, whereas IL- $1 \beta$ seemed to be found mostly in the dermal fraction of TNF $\alpha$ transgenic skin. That IL-1 acts synergistically with TNF $\alpha$ has been strongly suggested from previous studies (Rothstein and Schreiber 1988; Schreiber et al. 1990).

A number of other cytokines have been implicated in mediating the effects of TNF $\alpha$, including IL-8, GM-CSF, $M-C S F$, G-CSF, and TGF- $\beta$ (for review, see Akira et al. 1990; Cerami 1992). Although we have not yet examined whether these other factors are induced in the skin of our TNF $\alpha$ mice, many of these factors are clearly candidates for producing some of the effects that we have observed in the skin. As future transgenic studies are conducted, the extent to which these factors contribute either linearly or synergistically to the wide range of effects observed here should become more apparent.

\section{Materials and methods}

Generation of transgenic mice

The vector pK14-TNF $\alpha-\mathrm{hGH}$ was constructed as outlined in the legend to Figure 1. Transgenic mice were generated as described (Vassar et al. 1989) and were identified by PCR analysis of ear DNAs.

\section{Assay for biological acitivity of TNF $\alpha$ in serum}

Serum TNF $\alpha$ levels were quantified as described previously (see Teng et al. 1991 and references therein). Serum samples from transgenic and control animals and recombinant hTNF $\alpha$ (Genentech, South San Francisco, CA) standards were serially diluted in culture medium in 96-well plates containing the TNF $\alpha$ sensitive cell line, 1591-RE3.5, isolated from a UV-induced murine skin tumor. After a 2-day incubation, $100 \mu \mathrm{l}$ of medium was removed from each well and was replaced with $20 \mu \mathrm{l}$ of a $5-\mathrm{mg} / \mathrm{ml}$ solution of 3-(4,5-dimethylthiazol-2-yl)-2,5-diphenyltetrazolium bromide (MTT; Sigma, St. Louis, MO) in PBS. Plates were incubated for an additional $4 \mathrm{hr}$, after which the dye was solubilized overnight with $100 \mu \mathrm{l}$ of $10 \%$ SDS, $0.01 \mathrm{~N} \mathrm{HCl}$. The absorbance from 570 to $650 \mathrm{~nm}$ was read on a Molecular Devices Vmax plate reader. Percent cytotoxicity-cytostasis was determined as follows: $\%$ cytotoxicity/cytostasis $=11-\mathrm{OD}$ of experimental well/average OD of control wells) $\times 100$.

Each point shown is the average of duplicate wells. A mouse anti-recombinant hTNF monoclonal antibody (TNF-E; 1,2 ) was added at a final concentration of $1 \mu \mathrm{g} / \mathrm{ml}$ to a duplicate round of test sera.

\section{PCR analyses}

Organs from two 3- to 4-week-old transgenic and control littermates were taken for analyses. In addition, skins from the backs of 6-day-old transgenic and control mice were removed and either used directly or subjected to a $15-\mathrm{min}$ incubation with $2 \mathrm{M}$ sodium bromide at $37^{\circ} \mathrm{C}$ to selectively remove the epidermis. Tissues were then snap-frozen in liquid nitrogen, ground to a frozen powder, and processed for total RNA isolation (Vassar et al. 1989). To synthesize single-stranded cDNA, $5 \mu \mathrm{g}$ of RNasefree, DNase-treated total RNA was mixed with $1 \mu \mathrm{g}$ of oligo(dT) primer, 30 units of reverse transcriptase (Seikagaku America, Inc.), and 40 units of RNasin (Promega Biotec, Madison, WI) in reaction buffer [ $100 \mathrm{~mm}$ Tris hydrochloride $(\mathrm{pH} 8.0$ ), $30 \mathrm{mM} \mathrm{KCl}$, $10 \mathrm{mM} \mathrm{MgCl}, 1 \mathrm{~mm}$ deoxynucleoside triphosphates] and incubated for $90 \mathrm{~min}$ at $42^{\circ} \mathrm{C}$. RNA was then hydrolyzed in $0.5 \mathrm{~N}$ $\mathrm{NaOH}$ for $30 \mathrm{~min}$ at $70^{\circ} \mathrm{C}$, and single-stranded cDNA was precipitated with ethanol. The cDNA pellet was washed with $70 \%$ ethanol and dissolved in TE buffer. cDNAs were amplified under conditions suggested by Perkin-Elmer Cetus, and reactions were analyzed by agarose gel electrophoresis. To ensure reliability, total RNA preparations were prepared from two different transgenic animals, and two rounds of PCR amplifications were conducted on each RNA sample. PCR bands were only generated from mRNA samples to which reverse transcriptase was added in the initial reaction, demonstrating that the PCR bands were from mRNA, rather than from genomic DNA.

The PCR primers used are listed below, with the predicted size of the amplified product given in parentheses (see also Murray et al. 1990). Primers were for (1) mouse $\beta$-actin (348 bp), 
5'-TGGAATCCTGTGGCATCCATGAAAC-3', 5'-TAAAACGCAGCTCAGTAACAGTCCG-3'; (2) mouse K14 (277 bp), 5'GCTCCGCTGCGAGATGGA-3', 5'-GTTCTTGGTGCGCAGGAC-3'; (3) hTNFa (695 bp), 5'-ATGAGCACTGAAAGCATGATCCGG-3', 5'-GCAATGATCCCAAAGTAGACCTGCCC$3^{\prime}$; (4) mTNF $\alpha$ (307 bp), 5'-GGCAGGTCTACTTTGGAGTCATTGC-3', 5'-ACATTCGAGGCTCCAGTGAATTCGG-3'; (5) mouse IL-6 (154 bp), 5'-TGGAGTCACAGAAGGAGTGGCTAAG-3', 5'-TCTGACCACAGTGAGGAATGTCCAC-3'; $(6)$ mouse IL-1 $\alpha(308 \mathrm{bp}), 5$-CTCTAGAGCACCATGCTAGAGAC-3', 5'-TGGAATCCAGGGGAAACACTG-3'; and (7) mouse IL-1 $\beta$ (151 bp), 5'-CTGAAGCAGCTATGGCAACT-3', 5'-GGATGCTCTCATCAGGACAG-3'.

\section{Light and electron microscopy studies}

Tissues were fixed and processed for immunohistochemistry with gold-conjugated secondary antibodies as described previously (Coulombe et al. 1989). Antibodies against keratins and filaggrin were used as described by Vassar and Fuchs (1991). Tissues were fixed and embedded for ultrathin sectioning as described previously (Coulombe et al. 1989). All fixatives were prepared in $0.1 \mathrm{M}$ sodium phosphate buffer $(\mathrm{pH} 7.4)$, supplemented with $0.5 \%$ glucose and $1.2 \mathrm{~mm} \mathrm{MgCl}_{2}$. After surgical removal, tissues were fixed in freshly prepared $2.5 \%$ glutaraldehyde, followed by postfixing in $1 \%$ osmium tetroxide and embedding in LX-112 (Ladd Research Industries, Burlington, VT). Thin sections $(50 \mathrm{~nm})$ were recovered on Parlodion- and carbon-coated nickel grids. Grids were washed three times in PBS and once in distilled water, dried on filter paper, and contrasted with $3 \%$ uranyl acetate and Reynolds lead citrate (see Coulombe et al. 1989). Prepared grids were then examined by use of a JEOL-CXIl electron microscope operated at $80 \mathrm{kV}$.

\section{Acknowledgments}

We thank Debra Dugger for preparing transgenic mice, and Dr. Pierre Coulombe for advice concerning the interpretation of the electron micrographs. We thank Anton Callaway and Ruth Esteves for analyses of transgenic mouse DNAs, Linda Degenstein for her willingness to provide technical expertise, Philip Galiga for artwork, Richard Palmiter (University of Washington, Seattle, WA) for the hGH sequences and advice, Dennis Roop (Baylor College of Medicine, Houston, TX) for anti-mouse K6 antiserum, Beverly Dale (University of Washington, Seattle, WA) for anti-mouse filaggrin antiserum, and Stuart Yuspa (NIH, Bethesda, MD) for anti-mouse Kl antiserum, Brian Fendly (Genentech, Inc.) for anti-recombinant hTNF mouse monoclonal antibody (TNF-E), and Paul J. Leibson (Mayo Clinic, Rochester, MN) for anti-mouse TNF. This work was supported by a grant from the Howard Hughes Medical Institute. E.F. is an investigator and J.C. is a research associate of the Howard Hughes Medical Institute. K.T. is a postdoctoral fellow funded by the Medical Research Council of Canada. H.S. and M.T. were supported by NIH grants R37 CA-22677, PO1-CA-19266, and RO1-CA37156.

The publication costs of this article were defrayed in part by payment of page charges. This article must therefore be hereby marked "advertisement" in accordance with 18 USC section 1734 solely to indicate this fact.

\section{References}

Akira, S., T. Hirano, T. Taga, and T. Kishimoto. 1990. Biology of multifunctional cytokines: IL6 and related molecules (IL) and TNF). FASEB I. 4: 2860-2867.

Beutler, G. and A. Cerami. 1989. The biology of cachectin/TNF:
A primary mediator of the host response. Annu. Rev. Immunol. 7: 625-655.

Beutler, B.A., I.W. Milsark, and A. Cerami. 1985. Cachectin/ tumor necrosis factor: Production, distribution, and metabolic fate in vivo. J. Immunol. 135: 3972-3977.

Beutler, B., N. Krochin, I.-W. Milsark, C. Luedke, and A. Cerami. 1986. Control of cachectin (tumor necrosis factor) synthesis: Mechanisms of endotoxin resistance. Science 232: 977-980.

Brenner, D.A., M. O'Hara, P. Angel, M. Chojkier, and M. Karin. 1989. Prolonged activation of jun and collagenase genes by tumour necrosis factor-alpha. Nature 337: 661-663.

Carswell, E.A., L.J. Old, R.L. Kassel, S. Green, N. Fiore, and B. Williamson. 1975. An endotoxin-induced serum factor that causes necrosis of tumors. Proc. Natl. Acad. Sci. 72: 36663670 .

Cerami, A. 1992. Inflammatory cytokines. Clin. Immunol. Immunopathol. 62: 503-510.

Coulombe, P.A., R. Kopan, and E. Fuchs. 1989. Expression of keratin $\mathrm{K} 14$ in the epidermis and hair follicle: insights into complex programs of differentiation. J. Cell Biol. 109: 22952312.

Djeu, J.Y., K.D. Blanchard, and A.L. Richards. 1988. Tumor necrosis factor induction by Candida albicans from human natural killer cells and monocytes. /. Immunol. 141: 40474052.

Fenjves, E.S., D.A. Gordon, L.K. Pershing, D.L. Williams, and L.B. Taichman. 1989. Systemic distribution of apolipoprotein E secreted by grafts of epidermal keratinocytes: Implications for epidermal function and gene therapy. Proc. Natl. Acad. Sci. 86: 8803-8807.

Fong, Y., K.J. Tracey, L.L. Moldawer, D.G. Hesse, K.B. Manogue, J.S. Kenney, A.T. Lee, G.C. Kuo, A.C. Allison, and S.F. Lowry, 1989. Antibodies to cachectin/tumor necrosis factor reduce interleukin I beta and interleukin 6 appearance during lethal bacteremia. J. Exp. Med. 170: 1627-1633.

Gordon, J.R. and S.J. Galli. 1990. Mast cells as a source of both preformed and immunologically inducible TNF-alpha/ cachectin. Nature 346: 274-276.

Griffiths, C.E., J.J. Voorhees, and B.J. Nickoloff. 1989. Characterization of intercellular adhesion molecule- 1 and HLA-DR expression in normal and inflamed skin: Modulation by recombination gamma interferon and tumor necrosis factor. $J$. Am. Acad. Dermatol. 20: 617-629.

Han, J., T. Brown, and B. Beutler. 1990. Endotoxin-responsive sequences control cachectin/tumor necrosis factor biosynthesis at the translational level. J. Exp. Med. 171: 465-475.

Keffer, J., L. Probert, H. Cazlaris, S. Georgopoulos, E. Kaslaris, D. Kioussis, and G. Kollias. 1991. Transgenic mice expressing human tumour necrosis factor: A predictive genetic model of arthritis. EMBO /. 10: 4025-4031.

Kock, A., T. Schwartz, R. Kirnbauer, A. Urbanski, P. Perry, J.C. Ansel, and T.A. Luger. 1990. Human keratinocytes are a source for tumor necrosis factor $\alpha$ : Evidence for synthesis and release upon stimulation with endotoxin or ultraviolet light. I. Exp. Med. 172: 1609-1614.

Munro, J.M., J.S. Pober, and R.S. Cotran. 1989. Tumor necrosis factor and interferon-gamma induce distinct patterns of endothelial activation and associated leukocyte accumulation in skin of Papio anubis. Am. J. Pathol. 135: 121-133.

Murray, L.J., R. Lee, and C. Martens. 1990. In vivo cytokine gene expression in $\mathrm{T}$ cell subsets of the autoimmune MRL-Mplpr/lpr mouse. Eur. I. Immunol. 20: 163-170.

Nelson, W. and T.-T. Sun. 1983. The 50- and 58-kdalton keratin classes as molecular markers for stratified squamous epithelia: Cell culture studies. J. Cell Biol. 97: 244-251. 
Oliff, A., D. Defeo-Jones, M. Boyer, D. Martinez, D. Kiefer, G. Vuocolo, A. Wolfe, and S.H. Socher. 1987. Tumors secreting in human TNF/cachectin induce cachexia in mice. Cell 50: $555-563$.

Piguet, P.F., G.E. Grau, and B. Allet. 1987. Tumor necrosis factor/cachectin is an effector of skin and gut lesions of the acute phase of graft-vs.-host disease. I. Exp. Med. 166: 12801289.

Piguet, P.F., G.E. Grau, and P. Vassalli. 1990. Subcutaneous perfusion of tumor necrosis factor induces local proliferation of fibroblasts, capillaries, and epidermal cells, or massive tissue necrosis. Am. J. Pathol. 136: 103-110.

Pillai, S., D.D. Bikle, T.E. Eessalu, B.B. Aggarwal, and P.M. Elias. 1989. Binding and biological effects of tumor necrosis factor alpha on cultured human neonatal foreskin keratinocytes. $J$. Clin. Invest. 83: 816-821.

Postlethwaite, A.E. and J.M. Seyer. 1990. Stimulation of fibroblast chemotaxis by human tumor necrosis factor $\alpha$ TNF $\alpha$ ) and a synthetic TNF $\alpha$ 31-68 peptide. J. Exp. Med. 172: 17491756.

Rampart, M., W. De Smet, W. Fiers, and A.G. Herman. 1989. Inflammatory properties of recombinant tumor necrosis factor in rabbit skin in vivo. I. Exp. Med. 169: 2227-2232.

Rothstein, J.L. and H. Schreiber. 1988. Synergy between tumor necrosis factor and bacterial products causes hemorrhagic necrosis and lethal shock in normal mice. Proc. Natl. Acad. Sci. 85: 607-611.

Sale, G.E., H.M. Shulman, B.B. Gallucci, and E.D. Thomas. 1985. Young rete ridge keratinocytes are preferred targets in cutaneous graft-versus-host disease. Am. I. Pathol. 118: $278-287$.

Sandgren, E.P., N.C. Luetteke, R.D. Palmiter, R.L. Brinster, and D.C. Lee. 1990. Overexpression of TGFalpha in transgenic mice: Induction of epithelial hyperplasia, pancreatic metaplasia, and carcinoma of the breast. Cell 61: 1121-1135.

Saxne, T., M.A. Palladino Jr., D. Heinegard, N. Talal, and F.A. Wollheim. 1988. Detection of tumor necrosis factor alpha but not tumor necrosis factor beta in rheumatoid arthritis synovial fluid and serum. Arthritis Rheum. 31: 1041-1045.

Schreiber, H., V.H. Gressler, M.N. Teng, J.L. Rothstein, and D.A. Rowley. 1990. Cytokines as effectors in tumor immunity. Human Cancer Immunol. 10: 747-764.

Sharpe, R.J., F.J. Margolis, M. Askari, E.P. Amento, and R.D. Granstein. 1988. Induction of dermal and subcutaneous inflammation by recombinant cachectin/tumor necrosis factor (TNF-alpha) in the mouse. I. Invest. Dermatol. 91: 353357.

Stephens, J.M. and P.H. Pekala. 1991. Transcriptional repression of the GLUT4 and C/EBP genes in 3T3-L1 adipocytes by tumor necrosis factor- $\alpha$. I. Biol. Chem. 266: 21839-21845.

Symington, F.W. 1989. Lymphotoxin, tumor necrosis factor, and gamma interferon are cytostatic for normal human keratinocytes. I. Invest. Dermatol. 92: 798-805.

Teng, M.N., B.H. Park, H.K.-W. Koeppen, K.J. Tracey, B.F. Fendly, and H. Schreiber. 1991. Long term inhibition of tumor growth by tumor necrosis factor in the absence of cachexia or T cell immunity. Proc. Natl. Acad. Sci. 88: 35353539.

Teumer, J., A. Lindahl, and H. Green. 1990. Human growth hormone in the blood of athymic mice grafted with cultures of hormone-secreting human keratinocytes. FASEB $I$. 4: 3245-3250.

Torti, F.M., B. Dieckmann, B. Beutler, A. Cerami, and G.N. Ringold. 1985. A macrophage factor inhibitors adipocyte gene expression: An in vitro model of cachexia. Science 229: 867-869.
Tracey, K.J., B. Beutler, S.F. Lowry, J. Merryweather, S. Wolpe, I.W. Milsark, R.J. Hariri, T.J. Fahey, A. Zentella, J.D. Albert, G.T. Shires, and A. Cerami. 1986. Shock and tissue injury induced by recombinant human cachectin. Science 234: 470-474.

Tracey, K.J., Y. Fong, D.G. Hesse, K.R. Manogue, A.T. Lee, G.C. Kuo, S.F. Lowry, and A. Cerami. 1987. Anti-cachectin/TNF monoclonal antibodies prevent septic shock during lethal bacteraemia. Nature 330: 662-664.

Tracey, K.J., H. Wei, K.R. Manogue, Y. Fong, D.G. Hesse, H.T. Hguyen, G.C. Kuo, B. Beutler, R.S. Cotran, A. Cerami, and S.F. Lowry. 1988. Cachectin/tumor necrosis factor induces cachexia, anemia and inflammation. J. Exp. Med. 167: 12111227.

Turksen, K., T. Kupper, L. Degenstein, I. Williams, and E. Fuchs. 1992. IL-6: Insights to its function in skin by overexpression in transgenic mice. Proc. Natl. Acad. Sci. 89: 50685072.

Urban, J.L., H.M. Shepard, J.L. Rothstein, B.J. Sugarman, and H. Schreiber. 1986. Tumor necrosis factor: A potent effector molecule for tumor cell killing by activated macrophages. Proc. Natl. Acad. Sci. 83: 5233-5237.

Vassar, R. and E. Fuchs. 1991. Transgenic mice provide new insights into the role of TGF- $\alpha$ during epidermal development and differentiation. Genes \& Dev. 5: 714-727.

Vassar, R., M. Rosenberg, S. Ross, A. Tyner, and E. Fuchs. 1989. Tissue-specific and differentiation-specific expression of a human K14 keratin gene in transgenic mice. Proc. Natl. Acad. Sci. 86: 1563-1567.

Vilcek, J., V.J. Palombella, D. Henriksen-DeStefano. C. Swenson, R. Feinman, M. Hirai, and M. Tsujmoto. 1986. Fibroblast growth enhancing activity of tumor necrosis factor and its relationship to other polypeptide growth factors. $J$. Exp. Med. 163: 632-643.

Yocum, D.E., L. Esparza, S. Dubry, J.B. Benjamin, R. Volz, and P. Scuderi. 1989. Characteristics of tumor necrosis factor production in rheumatoid arthritis. Cell. Immunol. 122: 131145 . 


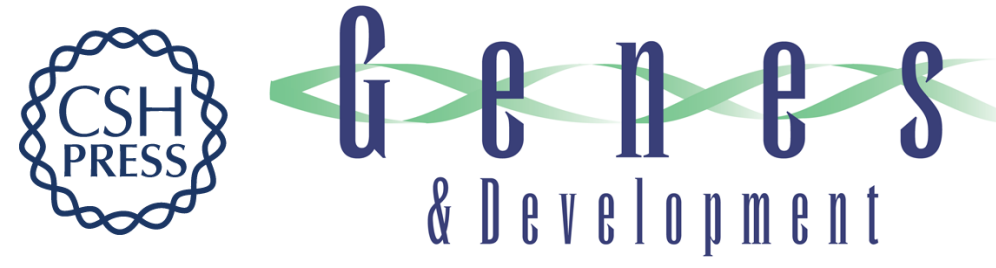

\section{Cachexia and graft-vs.-host-disease-type skin changes in keratin promoter-driven TNF alpha transgenic mice.}

J Cheng, K Turksen, Q C Yu, et al.

Genes Dev. 1992, 6:

Access the most recent version at doi:10.1101/gad.6.8.1444

References This article cites 45 articles, 24 of which can be accessed free at: http://genesdev.cshlp.org/content/6/8/1444.full.html\#ref-list-1

License

Email Alerting

Service

Receive free email alerts when new articles cite this article - sign up in the box at the top right corner of the article or click here.

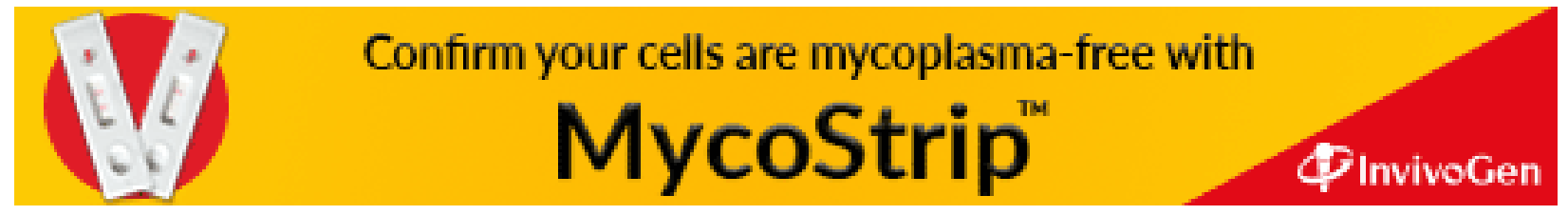

